\title{
Could the use of bone morphogenetic proteins in fracture healing do more harm than good to our patients?
}

\author{
Domagoj Delimar • Tomislav Smoljanovic • Ivan Bojanic
}

Received: 26 September 2011 / Accepted: 14 October 2011 /Published online: 4 November 2011

(C) Springer-Verlag 2011

\section{Dear Editor,}

Lissenberg-Thunnissen et al. evaluated the application of bone morphogenetic proteins (BMPs) in delayed bone repair, aiming at a broad audience from clinicians to scientists [1]. Among the adverse effects of BMPs, stimulation of cancer cells, development of antibodies, ectopic bone formation in fracture healing and critical soft tissue swelling for cervical spine fusions were listed. The authors mentioned that the adverse effects were associated with the use of very high BMP doses in animal studies, that they varied among species and that ultimately remodelling to the normal bone contour occurred.

It should be emphasised that several clinically significant adverse effects of BMPs were ignored in the review article. For instance, Laursen et al. have concluded that application of BMPs to a fracture site in humans might result in increased bone resorption as a primary event, which would be detrimental [2]. Such aggressive resorption of allograft and local bone has caused a higher nonunion rate leading to termination of BMP use in several clinical settings [2-4]. Furthermore, BMP use has caused local inflammatory responses at several anatomical locations such as spinal nerve roots (causing radiculitis), the superior hypogastric plexus (causing retrograde ejaculation), pleural tissue (causing pleural effusion), neck tissue (causing life-threatening conditions), subcutaneous tissue (causing wound healing problems and infections), etc. [5]. Even the ectopic bone formation mentioned did not always ultimately resolve with remodelling to normal bone contour, but rather it increased reoperation rates $[6,7]$.

Carragee et al. have recently found that the risk of adverse events associated with BMPs is ten to 50 times the original

\footnotetext{
D. Delimar · T. Smoljanovic $(\triangle) \cdot$ I. Bojanic

Department of Orthopaedic Surgery,

University Hospital Center Zagreb, School of Medicine,

Zagreb University,

Salata 7, 10000 Zagreb, Croatia

e-mail: drsmoljanovic@yahoo.com
}

estimates reported in the industry-sponsored peer-reviewed publications [5]. Considering that practically all bone fractures can be resolved by using correct treatment indications, meticulous surgical technique and modern surgical equipment (in combination with, when occasionally necessary, autologous bone grafting), the widespread shift to BMP use seems medically unjustified, economically more expensive and even potentially harmful. Therefore, it is of utmost importance for the broader audience, from clinicians to scientists, to be thoroughly informed about all clinically significant adverse effects of BMPs.

\section{References}

1. Lissenberg-Thunnissen SN, de Gorter DJ, Sier CF, Schipper IB (2011) Use and efficacy of bone morphogenetic proteins in fracture healing. Int Orthop 35:1271-1280. doi:10.1007/s00264-011-1301-z

2. Laursen M, Høy K, Hansen ES, Gelineck J, Christensen FB, Bünger CE (1999) Recombinant bone morphogenetic protein-7 as an intracorporal bone growth stimulator in unstable thoracolumbar burst fractures in humans: preliminary results. Eur Spine J 8:485-490

3. Kärrholm J, Hourigan P, Timperley J, Razaznejad R (2006) Mixing bone graft with OP-1 does not improve cup or stem fixation in revision surgery of the hip: 5-year follow-up of 10 acetabular and 11 femoral study cases and 40 control cases. Acta Orthop 77:39-48

4. Pradhan BB, Bae HW, Dawson EG, Patel VV, Delamarter RB (2006) Graft resorption with the use of bone morphogenetic protein: lessons from anterior lumbar interbody fusion using femoral ring allografts and recombinant human bone morphogenetic protein-2. Spine (Phila Pa 1976) 31:E277-E284

5. Carragee EJ, Hurwitz EL, Weiner BK (2011) A critical review of recombinant human bone morphogenetic protein-2 trials in spinal surgery: emerging safety concerns and lessons learned. Spine J 11:471-491. doi:10.1016/j.spinee.2011.04.023

6. Boraiah S, Paul O, Hawkes D, Wickham M, Lorich DG (2009) Complications of recombinant human BMP-2 for treating complex tibial plateau fractures: a preliminary report. Clin Orthop Relat Res 467:3257-3262. doi:10.1007/s11999-009-1039-8

7. Wong DA, Kumar A, Jatana S, Ghiselli G, Wong K (2008) Neurologic impairment from ectopic bone in the lumbar canal: a potential complication of off-label PLIF/TLIF use of bone morphogenetic protein-2 (BMP-2). Spine J 8:1011-1018 